\title{
ANALISIS NILAI PERCENTAGE DEPTH DOSE(PDD) TERHADAP VARIASI KEDALAMAN TARGET DAN LUAS LAPANGAN PENYINARAN MENGGUNAKAN PESAWAT LINAC-CX
}

\author{
Dian Milvita*, Alimin Mahyudin, Vinny Alvionita \\ Jurusan Fisika, FMIPA, Universitas Andalas, Limau Manis, Padang 25163 \\ *E-mail korespondensi: dianmilvita74@gmail.com
}

\begin{abstract}
Percentage Depth Dose (PDD) value measurement is done by varying the target depth and field size. The study was carried out with variations in target depth of $0 \mathrm{~cm}$ to $30 \mathrm{~cm}$ with $1 \mathrm{~cm}$ intervals and fields size ranging from $(5 \times 5) \mathrm{cm}^{2}$ to $(39 \times 39) \mathrm{cm}^{2}$ with intervals $(2 \times 2) \mathrm{cm}^{2} . P D D$ is a comparison of the radiation dose at a depth to the radiation dose at the maximum depth normalized by percentage. This study was also conducted to determine the value of radiation doses received by phantoms from the PDD measurement value. This research used 2 photon energy beam that is $6 \mathrm{MV}$ and $10 \mathrm{MV}$. This study uses water phantom as a substitute for patients with radiation source technique Source Surface Distance (SSD). PDD measurements were performed using a chamber ionization detector. The results obtained showed that the number of radiation doses received by fantom increased to the maximum depth $\left(z_{\max }\right)$. After passing $z_{\text {maks, }}$, the radiation dose received by the phantom has decreased. Likewise along with the increase in the amount of radiation field, the value of radiation doses received by phantoms will also increase.
\end{abstract}

Keywords: maximum depth $\left(\mathrm{z}_{\mathrm{maks}}\right)$, Percentage Depth Dose (PDD), Source Surface Distance (SSD).

\begin{abstract}
ABSTRAK
Telah dilakukan pengukuran nilai Percentage Depth Dose (PDD) dengan memvariasikan kedalaman target dan luas lapangan penyinaran. Variasi kedalaman target mulai $0 \mathrm{~cm}$ hingga $30 \mathrm{~cm}$ dengan interval $1 \mathrm{~cm}$ dan luas lapangan penyinaran mulai dari (5x5) $\mathrm{cm}^{2}$ hingga (39x39) $\mathrm{cm}^{2}$ dengan interval (2x2) $\mathrm{cm}^{2} . P D D$ merupakan perbandingan dosis radiasi di suatu kedalaman terhadap dosis radiasi di kedalaman maksimum dinormalisasi dengan persentase. Penelitian juga dilakukan untuk menentukan nilai dosis radiasi yang diterima fantom dari nilai pengukuran PDD. Penelitian menggunakan 2 berkas energi foton yaitu $6 \mathrm{MV}$ dan $10 \mathrm{MV}$ serta fantom air sebagai pengganti pasien dengan teknik penyinaran Source Surface Distance (SSD). Pengukuran PDD dilakukan menggunakan detektor ionisasi chamber. Hasil penelitian menunjukkan bahwa semakin bertambah kedalaman target maka semakin meningkat nilai dosis radiasi yang diterima fantom sampai mencapai kedalaman maksimum $\left(z_{\text {maks }}\right)$. Setelah melewati $z_{\text {maks }}$ maka nilai dosis radiasi yang diterima fantom mengalami penurunan. Begitupun seiring dengan bertambahnya luas lapangan penyinaran, maka nilai dosis radiasi yang diterima fantom juga akan meningkat.
\end{abstract}

Kata kunci: Percentage Depth Dose (PDD), Source Surface Distance (SSD), kedalaman maksimum ( $\left.\mathrm{z}_{\mathrm{maks}}\right)$.

\section{PENDAHULUAN}

Kanker merupakan salah satu penyakit yang mengganas dan dapat merusak organ penting tubuh lainnya jika dibiarkan terus menerus tumbuh. Oleh karena itu perlu dilakukan pengobatan terhadap kanker dengan salah satu cara menggunakan radiasi. Pemanfaatan radiasi dalam mengobati kanker dikenal dengan radioterapi. Bersama-sama dengan bedah onkologi dan pengobatan dengan kemoterapi, radioterapi telah berhasil meningkatkan angka kesembuhan penyakit kanker [1]. Menurut Perka Bapeten, 
radioterapi adalah modalitas pengobatan dengan menggunakan zat radioaktif terbungkus dan/atau pembangkit radiasi pengion. Radioterapi terdiri dari brakiterapi dan teleterapi. Brakhiterapi adalah jenis radioterapi jarak dekat yang diberikan secara manual atau remote after loading. Terapi eksternal (teleterapi) adalah jenis radioterapi dengan peralatan pemancar berkas radiasi berada pada jarak tertentu di luar tubuh manusia [2].

Jarak dari pemancar berkas radiasi ke target radiasi dalam teleterapi diberikan dalam dua teknik penyinaran yaitu teknik Source Surface Distance (SSD) dan teknik Source Axis Distance (SAD). Teknik SSD merupakan teknik penyinaran dimana diberikan jarak tertentu dari sumber radiasi ke permukaan tubuh, sedangkan teknik SAD merupakan teknik penyinaran dimana sumber radiasi diberikanpada jarak tertentu ke titik isosenter. Teknik SSD dan SAD digunakan pada salah satu instrumen radioterapi yaitu Linear Accelerator (LINAC). LINAC pertama kali digunakan oleh rumah sakit di London yakni Hammer Smith Hospital untuk keperluan medik. Pesawat LINAC dapat menghasilkan dua berkas radiasi yaitu berkas foton dan berkas elektron. Berkas elektron dapat digunakan untuk mengobati tumor superficial (permukaan kulit), sedangkan berkas foton dapat digunakan untuk mengobatai tumor dalam jaringan tubuh seperti kanker nasofaring, kanker serviks dan kanker payudara. Pemilihan berkas radiasi sangat penting terhadap penerimaan dosis radiasi, oleh karena itu diperlukan ketepatan dalam pemberian dosis radiasi. Pemberian dosis radiasi bergantung pada kedalaman, jenis kanker dan tujuan pengobatan. Parameter lain dalam ketepatan pemberian dosis radiasi adalah ketepatan penggunaan lapangan penyinaran dalam radiasi. Luas lapangan penyinaran dan kedalaman target berkaitan dengan nilai Percentage Depth Dose (PDD). PDD merupakan perbandingan dosis radiasi di kedalaman tertentu terhadap dosis radiasi di kedalaman maksimum dinormalisasi dalam persentase. Nilai PDD akan digunakan dalam menentukan berapa nilai dosis radiasi yang diterima oleh pasien. PDD bergantung pada 4 faktor yaitu kedalaman, luas lapangan pennyinaran, jarak sumber ke permukaan (SSD) dan energi berkas radiasi.

Penelitian mengenai pengukuran nilai PDD telah dilakukan Sidabutar dkk menggunakan pesawat Co-60 dengan variasi kedalaman $(1,3,5,7,9) \mathrm{cm}$ dan luas lapangan bentuk persegi dan persegi panjang [3]. Selanjutnya Laksono dkk melakukan studi komparasi metode Percentage Depth Dose (PDD) dan Tisuue Maximum Ratio (TPR) pada pesawat LINAC dengan variasi kedalaman (0-25) $\mathrm{cm}$ dengan luas lapangan penyinaran $(10 \times 10) \mathrm{cm}^{2}[4]$.

Pada penelitian ini dilakukan analisis nilai PDD terhadapvariasi kedalaman target dan luas lapangan penyinaran. Variasi kedalaman target yang digunakan mulai dari $0 \mathrm{~cm}$ hingga $30 \mathrm{~cm}$ dengan interval $1 \mathrm{~cm}$ dan luas lapangan penyinaran dimulai dari $(5 \times 5) \mathrm{cm}^{2}$ hingga (39x39) $\mathrm{cm}^{2}$ dengan interval $(2 \times 2) \mathrm{cm}^{2}$. Nilai PDD tersebut digunakan untuk menghitung nilai dosis radiasi yang diterima pasien. Penelitian menggunakan pesawat LINAC tipe Clinac-CX dengan berkas energi foton $6 \mathrm{MV}$ dan 10 MV di RS Universitas Andalas.

\section{METODE PENELITIAN}

Penelitian dilakukan di dalam fantom air yang diisi dengan aquades dengan menggunakan detektor ionisasi chamber. Penelitian diawali dengan mengukur nilai PDD pada kondisi referensi yaitu pada kedalaman $10 \mathrm{~cm}$ dengan luas lapangan penyinaran $10 \times 10 \mathrm{~cm}^{2}$. Selanjutnya dilakukan pengukuran PDD dari variasi kedalaman target dan luas lapangan penyinaran. Pengukuran dimulai dengan memvariasikan kedalaman target dimulai dari $0 \mathrm{~cm}$ hingga $30 \mathrm{~cm}$ dan luas lapangan penyinaran dari $(5 \times 5) \mathrm{cm}^{2}$ hingga (39x39) $\mathrm{cm}^{2}$ dengan interval $2 \mathrm{~cm}$. Penyinaran dimulai dengan energi $6 \mathrm{MV}$, selanjutnya nilai PDD akan terbaca ketika detektor telah bergerak dari dasar hingga ke permukaan. 
Lalu, pengukuran dilanjutkan dengan energi 10 MV. Setelah didapatkan nilai PDD, lalu dicatat di komputer, kemudian nilai PDD tersebut digunakan untuk menghitung nilai dosis radiasi yang diterima pasien menggunakan Persamaan (1).

$D=M U \times\left(\frac{D}{M U}\right)_{(z, f, A, h v)} \times F \times P D D$

dengan $D$ adalah dosis radiasi (cGy), $M U$ adalah monitor unit, $F$ adalah output faktor dan PDD merupakan Percentage Depth Dose.

\section{HASIL DAN PEMBAHASAN}

\section{Pengukuran nilai Percentage Depth Dose (PDD) pada energi foton $6 \mathrm{MV}$}

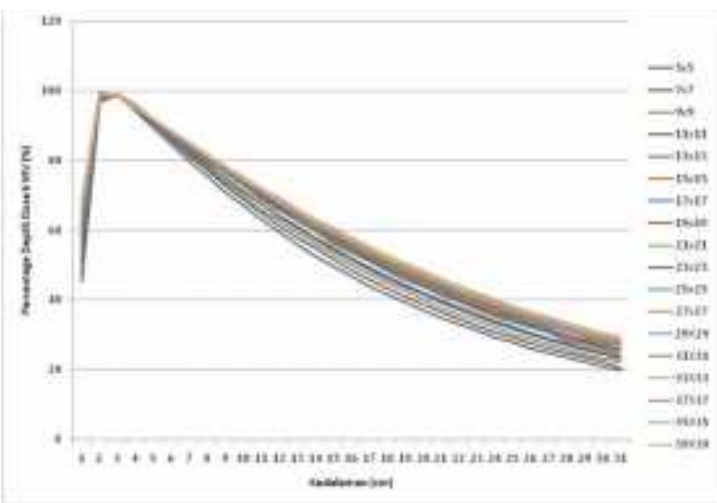

Gambar 1. Plot nilai Percentage Depth Dose (PDD) terhadap kedalaman target dan luas lapangan penyinaran pada energi $6 \mathrm{MV}$.

Setelah dilakukan pengukuran PDD dan dosis radiasi, maka didapatkan grafik hubungan antara kedalaman target dan luas lapangan penyinaran. Pada Gambar 1 yaitu plot nilai PDD dari variasi kedalaman target dan luas lapangan penyinaran dengan energi foton 6 MV. Hasil yang didapatkan menunjukkan bahwa semakin bertambah kedalaman target maka nilai PDD dan nilai dosis radiasi yang diterima fantom akan semakin meningkat hingga mencapai kedalaman maksimum $\left(z_{\text {maks }}\right)$. Setelah melewati $z_{\text {maks }}$ nilai PDD yang diterima fantom mengalami penurunan karena adanya atenuasi foton dan inverse square law. Luas lapangan penyinaran juga berpengaruh terhadap nilai PDD yang diterima fantom, nilai PDD akan meningkat seiring dengan bertambahnya luas lapangan penyinaran. Selanjutnya pada berkas foton berenergi $6 \mathrm{MV}$ nilai $z_{\text {maks }}$ berkisar antara $(1,35-1,75) \mathrm{cm}$.

\section{Pengukuran nilai Percentage Depth Dose (PDD) pada energi foton $10 \mathrm{MV}$}

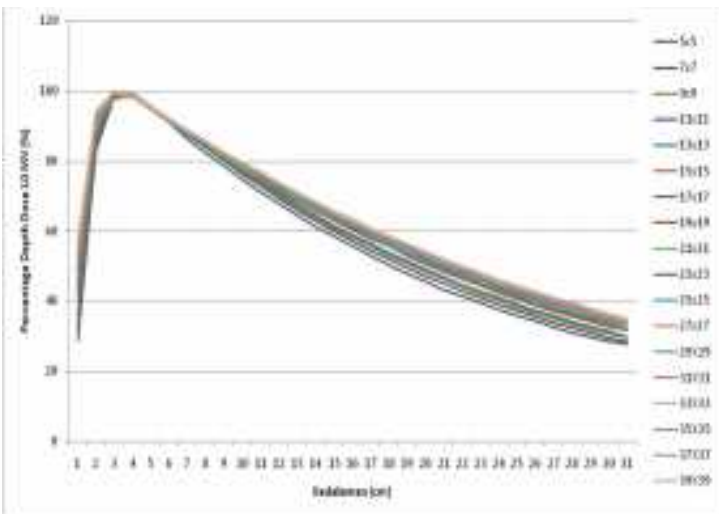

Gambar 2 Plot nilai Percentage Depth Dose (PDD) terhadap variasi kedalaman target dan luas lapangan penyinaran pada energi 10MV.

Hubungan antara PDD dengan kedalaman dan luas lapangan penyinaran pada energi 10 MV dapat dilihat pada Gambar 2. Hasil yang didapatkan nilai PDD yang diterima fantom meningkat seiring dengan bertambahnya kedalaman target namun hanya sampai $z_{\text {maks }}$, setelah melewati $z_{\text {maks }}$ nilai PDD yang diterima fantom mengalami penurunan. Begitupun dengan pengaruh dari variasi luas lapangan penyinaran, nilai PDD akan meningkat dengan bertambahnya luas lapangan penyinaran. Pada berkas foton berenergi $10 \mathrm{MV}$ nilai $z_{\text {maks }}$ yang didapatkan lebih besar dibandingkan dengan 6 MV yaitu berkisar antara $(2,25-2,45) \mathrm{cm}$. Nilai $z_{\text {maks }}$ pada energi 10 MV lebih besar dibandingkan 6 MV diakibatkan karena adanya penyerapan energi didalam air [4].

\section{Pengukuran nilai dosis radiasi pada energi foton $6 \mathrm{MV}$}

Nilai dosis radiasi diperolah menggunakan Persamaan (1) dari hasil pengukuran PDD. Pada Persamaan (1) terdapat nilai MU yang 
merupakan monitor unit atau satuan penyinaran yang akan diberikan pada pasien saat penggunaan LINAC. Nilai MU yang digunakan pada perhitunga dosis radiasi adalah 100 MU. Nilai MU ini disesuuaikan dengan yang ada TRS 398 [5] bahwa seharusnya nilai $1 \mathrm{MU}$ harus sama dengan 1 cGy. Gambar 3 merupakan plot nilai dosis radiasi dari variasi kedalaman target dan luas lapangan penyinaran pada energi foton $6 \mathrm{MV}$

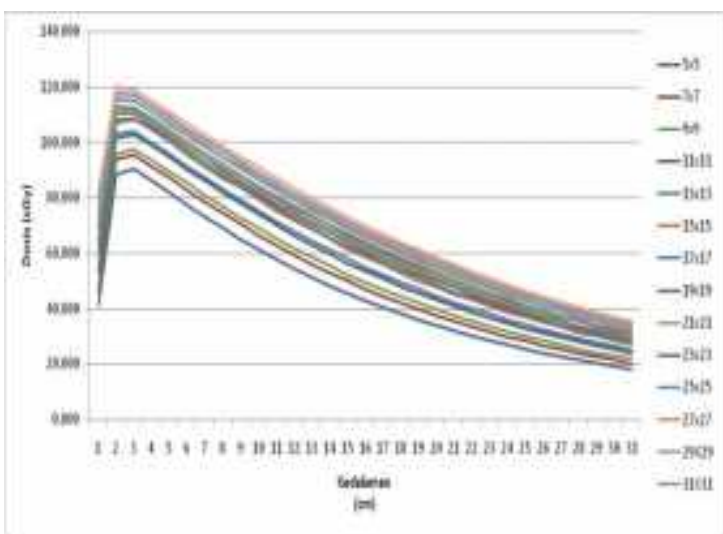

Gambar 3. Plot nilai dosis radiasi dari variasi kedalaman target dan luas lapangan penyinaranpada energi foton $6 \mathrm{MV}$.

Hasil yang didapatkan menunjukkan bahwa nilai dosis radiasi yang diterima fantom mengalami peningkatan seiring dengan bertambahnya kedalaman target, namun hanya sampai mencapai kedalaman maksimum $\left(z_{\text {maks }}\right)$. Setelah melewati $z_{\text {maks }}$ nilai dosis radiasi yang diterima fantom cenderung mnegalami penurunan sebagai mana pada hasil pengukuran PDD.

\section{Pengukuran nilai dosis radiasi pada energi foton $10 \mathrm{MV}$}

Nilai dosis radiasi menggunakan berkas energi foton $10 \mathrm{MV}$ dapat dilihat pada Gambar 4. Hasil yang didapat menunjukkan bahwa nilai dosis radiasi yang diterima fantom mengalami kenaikan hingga mencapai kedalaman maksimum $\left(z_{\text {maks }}\right)$, namun setelah melewati $z_{\text {maks }}$ nilai dosis radiasi yang diterima fantom mengalami penuruan akibat adanya atenuasi foton. Saat mencapai nilai $z_{\text {maks }}$, nilai dosis radiasi meningkat, hal ini disebabkan karena pada kedalaman tersebut jumlah ionisasi meningkat sehingga menyebabkan produksi foton juga meningkat [5].

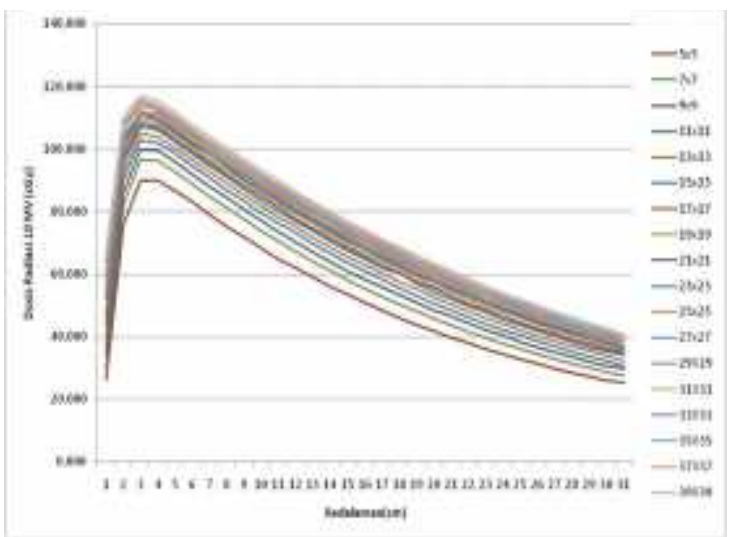

Gambar 4. Plot nilai dosis radiasi dari variasi kedalaman target dan luas lapangan penyinaran pada energi foton $10 \mathrm{MV}$.

\section{KESIMPULAN}

Pada pengukuran Percentage Depth dose (PDD) dan perhitungan nilai dosis radiasi menggunakan pesawat terapi LINAC tipe Clinac CX didapatkan bahwa nilai dosis radiasi yang diterima fantom mengalami kenaikan seiring dengan meningkatnya kedalaman namun hanya sampai kedalaman maksimum $\left(z_{\text {maks }}\right)$. Setelah melewati $z_{\text {maks }}$ nilai PDD dan dosis radiasi cenderung menurun dikarenakan adanya atenuasi foton dan inverse square law. Nilai PDD dan dosis cenderung naik seiring dengan meningkatnya luas lapangan penyinaran. Nilai kedalaman maksimum $\left(z_{\text {maks }}\right)$ yang didapatkan dari hasil pengukuran untuk foton berenergi $6 \mathrm{MV}$ berkisar antara $(1,35-1,75) \mathrm{cm}$ dan untuk foton berenergi $10 \mathrm{MV}$ berkisar $(2,25-2,55) \mathrm{cm}$. Nilai $z_{\text {maks }}$ yang didapatkan sesuai dengan batasan yang ditetapkan oleh IAEA.

\section{UCAPAN TERIMAKASIH}

Peneliti mengucapkan terima kasih kepada FMIPA Universitas Andalas yang telah membiayai penelitian melalui dana PNBP tahun Anggaran 2018 dan pihak Instalasi Radioterapi RS Unand untuk fasilitas yang diberikan selama penelitian. 


\section{REFERENSI}

1. Susworo. (2007). Radioterapi. Jakarta: UIPress, 1.

2. BAPETEN. (2013). Perka BAPETEN No.3 Tahun 2013 tentang Keselamatan Radiasidalam Penggunaan Radioterapi, https://jdih.bapeten.go.id/index.php/site/do kview/id/321. diakses September 2018,

3. Sidabutar, D. H. \& Setiawati, E. (2014). Perbandingan Dosis Terhadap Variasi Kedalaman dan Luad Lapangan Penyinaran (Bentuk Persegi dan Persegi Panjang) Pada Pesawat Terapi Cobalt-60. Youngster Physics Journal, 3(4), 295-302.
4. Laksono, M. B, Wardaya, S., Budi, W. S, \& Hidayanto, E. (2015). Studi Komparasi Metode Percentage Depth Dose (PDD) dan Tissue Phantom Ratio (TPR) Untuk Menentukan Indeks Kualitas Berkas Energi 6 MV dan 10 MV Pada Pesawat LINAC.Berkala Fisika, 18(1), 1-8.

5. Khan, F. M. (1984). The Physics Of Radiation Therapy Third Edition. Minneapolis: Uniuersig of Minnesota Medical School, 162-196. 